\title{
MEMORIAL
}

\section{WILLIAM CULP DARRAH}

$$
\text { (1909-1989) }
$$

William C. Darrah, educator, geologist, botanist, and historian, loved life, and he chose to share with others his genuine enjoyment of discovery and learning through his writing and teaching. His $A$ Critical Review of the Upper Carboniferous Floras of the Eastern United States (1970) and nearly a hundred professional papers made his name familiar to many paleontologists in Pennsylvania and throughout the United States. It is interesting to note that early in his career Bill developed an interest in the early conifers, especially Walchia. At the time of his death, he had just completed a manuscript with Paul Lyons, "The Earliest Conifers in North America: Upland and/or Paleoclimatic Indicators?," which has been accepted for publication in PALAIOS. Most recently, having attended the International Geological Conference in the United States in 1933, Bill had hoped to present a paper on the Dunkard at the July 1989 IGC in Washington, D.C.

Over a lifetime, Bill made great contributions to paleobotany and geology. Even so, many still may know little about his extraordinary life.

William (Bill) Darrah was born in Reading, Pennsylvania, on January 12, 1909. He received his B.S. degree from the University of Pittsburgh in 1931. Following graduate studies, he went on to Harvard University in 1934, first as a research assistant and then as research curator in paleobotany at the Botanical Museum as well as faculty instructor in biology until 1942. During the war years, Bill devoted nine years as an assistant head research engineer in the Research \& Development Laboratory of Raytheon Manufacturing Company of Waltham, Massachusetts.

In 1951, he moved his family to Gettysburg, Pennsylvania, where he resumed his various research and writing activities. In 1953, he joined the faculty of Gettysburg College. Awarded a full professorship in 1963, he remained there until his retirement in 1976. Gettysburg College awarded him the honorary degree of Doctor of Humane Letters in 1977.

Throughout his long career, William Darrah published more than 13 books, including Principles of Paleobotany (2nd edition, 1960), Textbook of Paleobotany (1939), The Exploration of the Colorado River (1940, 1950), Powell of the Colorado (1951), and Pithole: the Vanished City (1972).

Although suffering from heart trouble and terminal cancer, Bill was always in good spirits. He was devoted to his family and remained committed to continuing his research and other educational pursuits. Interested in people, he was a patient listener, an enthusiastic talker, a concerned guide to friends, colleagues, students alike.

Elsie Darrah Morey Norristown, Pennsylvania 